\title{
Communication in a Multicultural Virtual Environment for Modern Slovak Students
}

\author{
Hedviga Tkáčová1 ${ }^{\mathbb{D}}$, Roman Králik ${ }^{2} \otimes$ \\ ${ }^{1}$ Catholic University in Ruzomberok, \\ 1 Hrabovská cesta, Ruzomberok, 034 01, Slovak Republic \\ ${ }^{2}$ Peoples' Friendship University of Russia (RUDN University), \\ 6 Miklukho-Maklaya St, Moscow, 117198, Russian Frderation \\ $\bigotimes$ roman.kralik73@gmail.com
}

\begin{abstract}
The necessity of establishing intercultural communication skills in children and young people is growing in the modern world. Expanding, extending the openness and accessibility of the Internet area, where diverse people with varied ideas, interests, and aspirations meet, plays a significant role in this process. Today's youth are aptly referred to as "digital aborigines," as they navigate the multicultural internet environment with ease, actively using modern technology that have already become a part of their daily lives. The goal of this study is to investigate the setting of an online multicultural environment from the perspective of Slovak university students, as well as to identify and analyze current problems that university students can see in online discussions about other cultures. A structured interview was used as the primary research approach. The results provide Slovak students' perspective on the six most common topics that resonate in connection with different cultures on the current Internet: (1) concerns about one's own safety due to "differences of others;" (2) misinformation on the Internet regarding "the difference of others;" (3) cognitive prejudice; (4) religious prejudices; (5) exaggeration; and (6) influencing audience emotions. This paper holds the view that modern young people should develop not only the ability to navigate in virtual reality, but also make daily personal efforts to overcome personal barriers and develop "intercultural media literacy," which the authors define as the ability to acquire, in addition to digital competencies, intercultural understanding skills and apply these skills in practice in the process of communication in the Internet environment.
\end{abstract}

Key words: multicultural environment, virtual environment, intercultural media literacy, students, media, structured interview

\section{Introduction}

Members of various cultural, ethnic, national or religious backgrounds have lived together in the Slovak cultural environment for centuries. The multiculturalism of Slovak society has not taken place and is still not going smoothly; on the contrary, the peaceful coexistence of various groups of people is also marked by preju- 
dices and stereotypes, which manifest themselves in various forms of intolerance. Not only in Slovakia, therefore, is the importance of supporting children and young people in their ability to move in a multicultural environment undeniable. At present, cultural diversity is even deepening due to several trends, for example the migration of the population, the freer movement of people and the development of tourism, online education that transcends the boundaries of state schools, and so on. It is therefore not surprising that the Slovak school system responds to new realities and already today "prepares pupils and students of all ages for their contact with various cultural influences."

"The traditional cultural diversity of Slovakia has been deepening in recent years also thanks to the opening of Slovak society with the help of Internet media" (Mistrík, 2011. P. 18). Young people come into contact with members of other cultures thanks to the virtual environment of the Internet, which is unlimited in time, accessible, its contents are updated at all times and allows the possibility of immediate feedback, i.e. two-way communication between users. In the words of media theorist D. McQuail, the Internet enables interactivity and flexibility of the offered content, which underlines the forms of representation and ways of utilization (McQuail, 2007). Spanish academic, journalist and writer I. Ramonet therefore likens the information system of the Internet and the ongoing digitization to such a radical revolution as Gutenberg's bookseller in 1440; the author talks about a new type of communication, which contains more than the existing system of three characters, i.e. written text, sound of speech and image (Ramonet, 2003).

The great advantage of today's Internet is that it allows instant communication, as well as the fast and efficient search, analysis, use, creation or publication of information ${ }^{2}$. In addition, the Internet also enables simple data compression, information storage and transmission (Snow et al., 2017), which has great application in education at all levels of schools. On the other hand, internet and online content also carry a greater risk of untruth (Reifová, 2004). We are thinking in particular about information with fraudulent nature or misleading, disinformation or propaganda claims that are inconsistent with the facts. The problem is also extremist content and include vulgarities, calls for violence and aggressive personal attacks as well as conspiracy theories and "nonsense", which can have more serious political, economic or health consequences. Fake news spreading through media outlets poses a real threat to the trustworthiness of information, emotional health of internet users and, ultimately, for the security of internet users as well as the whole society (Webb et al., 2016).

Some experts characterize the Internet as unrestrained environment similarly in negative context because they see the Internet mainly related to the attribute of anonymity (Vybíral, 2002; Veličková-Hulanová, 2012; Šmahel, 2003). According to experts, it is especially anonymity, which is very attractive for participants of the virtual environment, and especially for people with intolerant behavior and a tendency to aggression. As professor and expert on media studies D. Šmahel

\footnotetext{
${ }^{1}$ State Educational Program. (2020). Retrieved from https://www.statpedu.sk/sk/svp/statnyvzdelavaci-program/svp-prvy-stupen-zs/prierezove-temy/multikulturna-vychova/

${ }^{2}$ Pettey, Ch. (2015). Embracing digital humanism. Retrieved from: https://www.gartner.com/smarterwithgartner/embracing-digital-humanism/
} 
pointed, if an Internet user has confidence in his or her subjective anonymity, they behave differently than in everyday life, where this anonymity is lacking. The consequence of such behavior can be described as "the loss of social barriers" (Šmahel, 2003).

The fact is, the internet audience is diverse, it represents a set of individual users with individual behaviour and individual perception (Jirák, Kopplová, 2009), which often leads to sharp interpersonal disputes, open invectives and hate speech to racism, xenophobia, anti-Semitism, ethnic discrimination, etc. The online media is becoming a space for sharing good ideas, as well as a place for reproducing stereotypical statements and prejudices, which implicitly leads to potentially intolerant behaviour towards "otherness." Theoretician of cultural studies and sociologist S. Hall points out that online stereotyping creates opposites and creates "differences" (between the individual and other people; between "own" and "different" groups) and fixes, so they do not disappear, but reappear (often even in different contexts) in virtual space (Hall, 2013). Figure 1 illustrates the process in which shared ideas on the Internet potentially lead to intolerant behaviour.

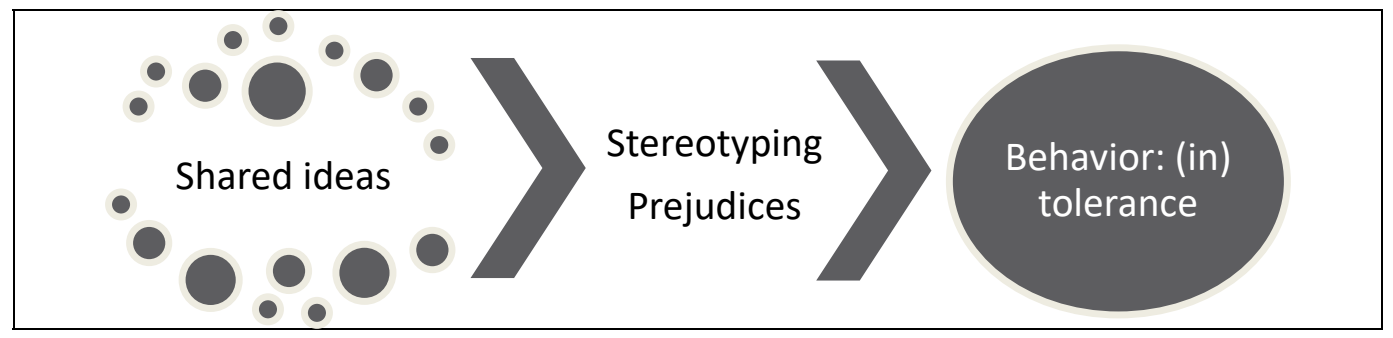

Figure 1. The process of intolerant behaviour

Source: custom processing.

In our opinion, the challenge for today's man is and will be more and more, not only to be able to orientate in virtual reality, but also everyday individual efforts to transcend personal boundaries and acquire not only the necessary digital competencies but also media literacy (Hobbs, Jensen, 2009; Cortoni, 2017; Fedorov, Mikhaleva, 2020), multicultural literacy (Jones, 2003; Derman-Sparks, Phillips, 1997), skills in understanding and using digital technologies (Welnitzová et al., 2021), and many of cultural competences, which represent "a set of behaviors, attitudes, skills and policies that enable individuals, organizations and staff to work effectively in cross-cultural situations" (Cross, 1989; Sue, 2001).

In this article, we will use the term "intercultural media literacy," by which we will mean the ability of an individual to acquire, in addition to digital competencies, the minimum basics of intercultural understanding, and apply them in practice in an unlimited internet environment. The aim of the paper is to explore the context and current topics of different cultures that university students have the opportunity to see in discussions about different cultures on the Internet.

The theoretical background is followed by our own research, the aim of which is to identify and evaluate current topics that researched students have the opportunity to see in discussions about different cultures on the Internet. Within the current multicultural and virtual educational environment, which was and still is influenced by COVID-19, we present a set of topics that, according to the respondents, 
are most often heard in connection with cultural, ethnic, religious or racial "differences" on the Internet. The research itself brings students a view of the six most common topics: (1) concerns about their own safety due to "differences of others;" (2) misinformation on the Internet regarding "the difference of others;" (3) cognitive prejudice; (4) religious prejudices; (5) exaggeration; (6) influencing audience emotions.

The research presents the current view of university students to the often controversial, which is a direct reference to the need for so-called "intercultural media literacy," by which we mean the individual's ability to master the minimum basics of intercultural understanding and know how to use them in the Internet.

\section{Methodology}

The aim of the whole research is to identify and evaluate current topics that university students in Slovakia have the opportunity to see in discussions about different cultures on the Internet.

For the sake of clarity and with the intention of highlighting the essentials of the research sample, we introduce firstly where research took place. Slovakia (former Czechoslovakia) is a member of the European Union, that neighbouring countries include Czech Republic, Hungary, Poland, Austria and Ukraine. With a population of 5 and a half million (in comparison to almost 448 million people in population of European Union), Slovakia is consider as one of the smallest landlocked country in Eastern Europe. The research sample of our research consist of eighteen university students from aged 19-23 from two universities in the middle part of Slovakia, and two universities from east of Slovakia.

The research had two separate parts and was conducted during four online meetings; one in first phase of the research, and three online meetings during the second phase. ZOOM was the platform through which all the research took place. The research was carried out in May 2021.

During the first stage of our research an online meeting was scheduled to identify topics, i.e., current topics that research students had faced about different cultures on the Internet. To meet this goal, we used structured interview. This method was implemented in the group of 18 students.

Structured interview was conducted with the help of three types of research questions:

a) general questions at the beginning of the research with the use of structured interview. Some examples: Do you think the inter-user debates are tolerant? Are you saying that there is a lot of intolerance in relation to different people on social networks, so to whom do you see intolerant attitudes the most? etc.;

b) we followed the interview with experience questions which gave respondents to be more specific. Some examples: Have you encountered with something you don't consider tolerant or ethical on the Internet? When you speak about stereotyping, how is your experience with online stereotyping on the Internet? Which prejudices have you noticed on the Internet? etc.;

c) third, we prepared such questions that could reflect the emotional status and reaction of the respondents on current topics that they have the opportunity to see in discussions about different cultures on the Internet. Some examples: How do online intolerant debates affect your feelings? Which of what we are talking about here now has the greatest impact on your well-being? etc. 
The result of structured interview method was six categories which, according to respondents, dominate the Slovak internet in relation to different cultures (i.e. research categories). We found these main topics about different cultures on the Slovak website from the perspective of respondents: (1) concerns about one's own safety due to "differences of others;" (2) misinformation regarding the "difference of others;" (3) cognitive prejudices; (4) religious prejudices (Jews, Muslims); (5) exaggeration; (6) influencing audience emotions. Moreover, based on interview, 14 research variables were formulated.

The second stage consists of evaluation of previously identified research categories and research variables, and was similarly conducted online via platform Zoom. Three interviews were conducted in such a way that students had to individually evaluate each of six research categories which were read orally to students; students' answers were further recorded on the form. The interview conducted in the form of three research groups, so we could better handle the evaluation.

While interview the students' task was to assign one point to those categories (i.e., topics) which respondents tend to see in discussions on the Internet, and zero point if they do not see topic in discussions on the Internet. Therefore, each research category could obtain a maximum of 18 points in the research sample $(\mathrm{n}=18)$. Based on the sum of points, we then created a sequence of the most common topics that, according to respondents, resonate about different cultures on the Slovak Internet.

It is possible to evaluate positively the answer of all questions by all respondents, meeting the time frame of the research, the economics of the chosen method and not deviating from the topic, to which the specific questions of the interview contributed.

The course of the interview was looser in places, and thus the data obtained are richer in terms of qualitative dimension. Similarly we could see five significant outcomes of used research method during the research:

1) interview as a method had potential to for overcome data collection;

2) interview as a method was well suited to the research of attitudes, values, motives or beliefs;

3 ) interview as a method ensured that the respondent is unable to receive assistance from others or be influenced by others while formulating a response;

4) interview as a method could facilitate comparability because researcher was able to ensuring that all questions are answered by each respondent;

5) interview as a method motivated respondents to participate and invite those people, who would otherwise not bother with a questionnaire or other research methods.

\section{Results and interpretation of results}

The research findings represent first the identification of the most common topics that the researched university students $(n=18)$ have the opportunity to see in discussions about different cultures on the Internet (Table) and then, secondly, the evaluation of these topics from the perspective of respondents $(n=18)$. Respondents' answers consist of several experiences, own concerns or specific examples of topics about different cultures, students had faced on the Internet. Respondents' experiences have qualitatively character and have essential cognitive value. 


\section{Identification of the most common topics about different cultures on the Internet}

As we can see in Table, these particular topics about different groups or cultures are heard in the online space according to respondents the most: (1) concerns about their own safety due to "differences of others;" (2) misinformation on the Internet regarding the "difference of others;" (3) cognitive prejudice; (4) religious prejudices against members of religious minorities, especially against Jews and Muslims. Female students in addition perceive moreover a belief in excessive (5) exaggeration. Students discussed about all previous categories and finally suggest a category (6) targeted influence of audience emotions.

Topics about different cultures on the Slovak website from the perspective of respondents

\begin{tabular}{|c|c|}
\hline Research categories & Research variables \\
\hline $\begin{array}{l}\text { Concerns about one's own safety } \\
\text { due to "differences of others" }\end{array}$ & $\begin{array}{l}\text { Individual security and state security; } \\
\text { the threat of intercultural conflicts; } \\
\text { refugee crisis and migration as tools to weaken Europe }\end{array}$ \\
\hline $\begin{array}{l}\text { Misinformation regarding the "dif- } \\
\text { ference of others" }\end{array}$ & $\begin{array}{l}\text { Examples of multicultural stereotypes from recent history with an in- } \\
\text { correct connection to the present; } \\
\text { disinformation contents (COVID-19, Arabs) }\end{array}$ \\
\hline Cognitive prejudices & $\begin{array}{l}\text { Theories about the hidden "enemy" that destroys our society; } \\
\text { demonization of "difference" }\end{array}$ \\
\hline Religious prejudices (Jews, Muslims) & $\begin{array}{l}\text { Jews in connection with COVID-19; } \\
\text { Muslims in connection with aggression and terrorism }\end{array}$ \\
\hline Exaggeration & $\begin{array}{l}\text { An argument that contains a sequence of statements to give a pic- } \\
\text { ture of the catastrophic consequences; } \\
\text { pessimism; } \\
\text { inadequate generalizations }\end{array}$ \\
\hline Influencing audience emotions & Twisted or false information that has the power to affect emotions \\
\hline
\end{tabular}

The category of "concerns for one's own security due to the difference of others" consists of statements by individuals in relation to individual or state security and statements by individuals in relation to the threat of intercultural conflicts. Respondents also make extensive reference to the refugee crisis and migration, which is emerging on the Internet in connection with the belief that migrants "are a tool to weaken Europe" (Jaroslav, 23). In the context of qualitative findings, students also talk about online debates about Europe's economic problems (e.g., growing poverty and social disparities), demographic problems (e.g., declining birth rates in European countries and rising birth rates among Muslims) or Europe's moral problems (especially rising social behaviour of immigrants), which "occurs as a result of the forced redistribution of refugees" (Matej, 19).

Students also identified "misinformation about differences" on the Internet. Among several examples of disinformation, they speak of stereotypes in relation to Hungarians (i.e., the southern neighbours of Slovaks), who are often associated on the Internet "with territorial claims to the southern part of Slovakia;" these are disinformation that have historical roots and are still revived in an incorrect way and connected to current events. Disinformation on the Internet also finds fertile ground in the context of anti-Arab topics. According to the respondents, the subject of fiction is mainly topics related to the activities of Muslim youth in Western countries, topics about Islamic law and punishments within Islam, or topics in the context of the rights of Islamic women living in Western countries. The domi- 
nating subjects that "split society," as per the respondents, are especially topics related to COVID-19. Respondents have repeatedly stated that vaccination of people "divides society" and "creates tension between the vaccinated and the unvaccinated" or "promotes public tabloidism or populism." Intergroup tensions and negativity arise, for example, between vaccinated and unvaccinated people. To the issue of intergroup tensions (e.g., between vaccinated and unvaccinated) for example Douglas points out (Douglas, 2021).

Based on the respondents' responses, we categorized cognitive prejudices into two basic categories. The first category consists, in the words of the respondent Martin (19), "theories about the hidden" enemy "who destroys our society." According to the respondents, there are frequent topics on the Internet with open anti-Roma sentiments. "Roma are commonly referred to on the Internet as "parasites" " (Mária, 22). Michal (23) also reflects the Roma as "societal pests" on social networks, according to which "within the discussion, Roma are often blamed for state financial assistance and their" subsistence "on public finances." The second category of cognitive prejudice is the "demonization of difference" in which respondents already talk about open verbal attacks against concrete culture, nationality, religion or ethnic group. Even in this case, according to the respondents, the most frequent addressees of openly hateful attitudes are mainly Roma. Surprising are a few of impropriate speeches against the Roma appears in the research group. Surprising are a few of impropriate speeches against the Roma appears. In parallel, couple of university students also show their reluctance to take into account any "mitigating" circumstances; for example, the negative consequences of demonstrable marginalization of Roma, i.e. they live in one of the least developed regions of the country, they live in segregated settlements, etc. (Kozubík et al., 2021).

As stated in J. Grác's psychological study, prejudices, including religious prejudices, identified by respondents in our research are negative attitudes of an individual against someone or something that resists change for a long time (Grác, 1985). Since prejudice is based on a strong identification with one's own group, the individual, according to Šišková or Boroš, leads to specific negative attitudes, i.e., distrust of hostility towards other individuals and groups (Šišková, 1998; Boroš, 2001). University students in our research indicated negativism and verbal attacks on the Internet relate primarily to the Jewish national minority and the Muslim minority. According to respondents, topics in which Jews are associated with the COVID-19 pandemic currently predominate on the Internet. "I read that the Jews initiated this disease to avenge the Holocaust" (Marek 23); "Jews are often referred to as spies, and various historical, ethical, and religious transgressions have been attributed to them on the Internet" (Eva, 21). In the words of Jaroslav (23), "passionate discussions can be found on the Internet about the economic power of Jews and their economic expansion." The latter, and the topic COVID-19, are mainly associated with the American financier of Jewish origin George Soros.

Religious prejudices against Muslims are relatively different. Respondents indicated that discussions about Muslims on the Internet tend to be associated with the image of Muslims as aggressors, fanatics and initiators of terrorist attacks. In parallel with this picture, a number of different inventions reach the young people surveyed in the online space. Based on our qualitative findings, 
consider the following to be the most widespread fabrications about Muslims on the Internet: (a) a priori negative relationship of Islam, resp. Muslims to non-Muslims, including the obligation of Muslims to fight unbelievers; (b) topics relating to the status of women in Islam that are interpreted in the context of the absence of any women's rights; (c) the importance and place of jihad in Islam, which is presented only as the so-called holy war; (d) the unity of the Islamic community, on the basis of which the image of a unified primarily "militant and hateful Islam" is formed. In the context of these findings, it is possible to agree with political scientist J. Lenč that Islamophobia in Slovakia (and in Europe in general) is aided by the fact that "a true picture of Islam does de facto not exist" (Lenč, 2017. P. 177).

We have termed "exaggeration" the category, consists of topics and arguments on the Internet that cover a series of statements to give a picture of the catastrophic consequences; in layman's terms we can speak of "hysteria." According to the respondents, "exaggeration" in the online space is again associated mainly with the Muslim minority (e.g. "Thanks to Muslims we will end badly", etc.). Some respondents state that in relation to Muslims, "this is not an exaggeration, but a real threat." Qualitative findings further extend this category to other phenomena. According to the respondents, exaggeration in the online space is accompanied by "inducing pessimism" and hand in hand also goes with "inappropriate generalizations" (e.g. "Everyone deceives us," etc.).

According to the respondents of our research, influencing the emotions of the audience is implicitly present in relation to all ethnic and religious groups. Although respondents may see distorted or false information on the Internet that has the power to affect emotions, many respondents state that they do not perceive the influence of emotions related to "cultural otherness" topics on the Internet. Rather, respondents are more sensitive to "hate speech and open negativism, which is unpleasant" (Eva, 22). Influencing the emotions of the audience is acknowledged by some students (although it is a minority). According to them, emotions can be influenced by, for example, the statements: "The corona is caused by unhygienic gypsies" or "Muslims - a beast that must return," etc.

\section{Evaluation of the most common topics about different cultures on the Internet}

The second part of our findings is the evaluation of the most common topics that the researched university students $(n=18)$ on the Internet find about different cultures (Figure 2).

An interesting finding is the evaluation of the most common topics on the Internet from the perspective of students. In the context of the examined audience attitude to "online diversity," eighteen respondents consider the following to be the most common three topics: (1) refugee crisis and migration, which are often portrayed as tools to weaken Europe on the Internet; (2) disinformation contents of various natures, but especially in relation to the COVID-19 pandemic; (3) cognitive prejudices, among which anti-Roma moods dominate.

Respondents evaluate religious prejudices as less common in the Slovak online environment. According to the respondents, less frequent topics on the Internet are also topics in the context of ethnic or religious differences, which would visibly affect the emotions of the audience. 


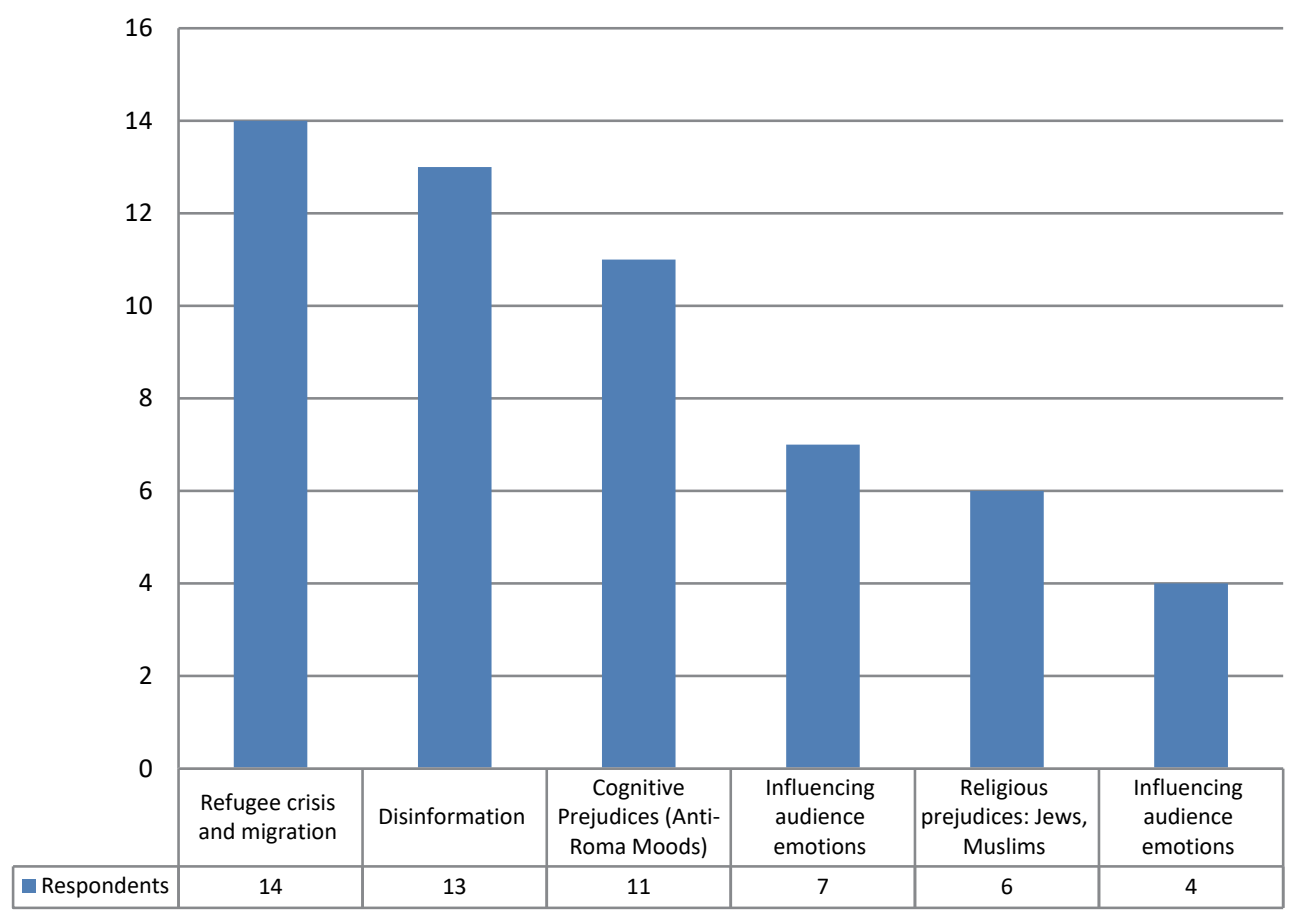

Figure 2. Frequencies of most common topics about different cultures on the Slovak website from the perspective of respondents

\section{Discussion}

The Slovak school system already "prepares pupils and students of all ages for their contact with various cultural influences." 3 This contact expands the Internet, in an environment in which today's young generation of "digital natives" feels natural and good (Procházka et al., 2014). This is despite the fact that, in addition to the necessary information, the necessary communication with peers or entertainment, he finds himself in an area where there are many lies (Reifová, 2004), disinformation that affects their immediate perception of reality and even security (Webb et al., 2016) or the anonymity (Vybíral, 2002; Veličková-Hulanová, 2012; Šmahel, 2003), which consequently in online space is described as "the loss of social barriers" (Šmahel, 2003. P. 14), as a result of which online content is created, which is in many ways directed against any "difference." At the same time, the popularity of extremism and right-wing parties is growing, and publicly presented hateful comments from individuals as well as social and political elites are appearing and tolerated (Charvát, 2007).

Besides that, some other experts proved that stereotypes, as well as disinformation, as a part of manipulated messages, passes from the past to the present, and are reflect especially in the environment of internet media, where there are characterized by recalling "differences" and "peculiarities" (Kondrla et al., 2020).

Finally, the current situation in connection with the COVID-19 pandemic has similarly negative impacts on the online environment where young people

${ }^{3}$ State Educational Program. (2020). Retrieved from https://www.statpedu.sk/sk/svp/statnyvzdelavaci-program/svp-prvy-stupen-zs/prierezove-temy/multikulturna-vychova/ 
spend the dominant part of their day due to education and are getting used to "flipped learning" (Khonamri et al., 2020), or in other words to the complex transformation from offline education to online education (Hašková et al., 2020), as well as they getting used to satisfy their needs to communicate, be informed or have fun basically only online.

Parallel to that, there are some negative phenomenon on the current Internet such as polarization of society, solitude "among people" and decline of people's lives and thus its quality (Murgaš, Petrovič, 2020), which might significantly influence young "generation of digital natives." Moreover, according to the Digital News Report $2020^{4}$ survey conducted by the Reuters Institute, it is very likely that a pandemic crisis will accelerate long-term structural change towards digital and mobile communications. In our opinion, a unique situation enters here practically from day to day - students, looking at their computer, are also looking at the multicultural environment in which they find themselves thanks to the unlimited possibilities of the Internet and rich stimuli in virtual education during a pandemic.

In the context of the findings, we see young people as opposed to multicultural and virtual reality as a vulnerable group that perceives risks but is not always able to deal with them. Qualitative findings confirm that the surveyed respondents are not always able to respond adequately to the multicultural environment. In many cases, the answer is "I don't know what to think about it" or just prompt condemnation of the actions of others: "I do not agree with this opinion" (Lenka, 20); "It's terrible what's on Facebook" (Eva, 22) or even expressing the consent "Everything I write there is still true" etc.

The facts outlined above lead us to believe that in the online environment, one of the key skills is the ability of university students to independently evaluate their own encounters with the "difference." It is a skill that each young person (and not just a young person) desperately needs if he or she is to join a diverse team in cyberspace, i.e., in an environment "without barriers," with "the loss of social barriers" (Šmahel, 2003. P. 14) and with an unimaginable amount of information and disinformation; i.e., on the place where, despite everything, this person also experiences common knowledge, communication, discovery and evaluation of the world around.

\section{Conclusion and recommendations}

This paper hold the view that the challenge for today's young people is and will be more and more, not only to be able to orient themselves in virtual reality, but also daily individual efforts to transcend personal boundaries and acquire multicultural literacy, abilities and skills for intercultural cooperation in addition to the necessary digital competences or the so-called "intercultural media literacy," which can be understood as the ability to acquire, in addition to digital competencies, also the minimum basics of intercultural understanding, and to apply them in practice in an unrestricted Internet environment.

Especially in connection with COVID-19, the young generation has immersed themselves even more in a world that exceeds their local culture, language

${ }^{4}$ Digital News Report. (2020). Foreword to the Reuters Institute Digital News Report 2020. Retrieved from: https://reutersinstitute.politics.ox.ac.uk/sites/default/files/2020-06/DNR_2020_FINAL.pdf 
or the educational and upbringing possibilities of the school. Therefore at the time of the corona crisis, knowing the thinking, actions or behavior of young people seems to be currently one of the priorities of effective online education. It is especially important to know the current changes in the young generation, which are related to the trends that shape this generation and affect it in many ways.

The aim of the article was to examine the context of a multicultural and at the same time virtual environment, from the point of view of university students. The theoretical background pointed on the opening of societies with the help of Internet media and contact with members of other cultures within virtual environment. On the other hand, online content carries many risks such as disinformation, fake news, attribute of anonymity (which is very attractive for virtual participants with intolerant behavior and a tendency to aggression), or stereotypical statements and prejudices (which implicitly lead to potentially intolerant behaviour towards "otherness"). Theoretical part had presented a challenge for today's man not to be only able to orientate in virtual reality, but also have everyday individual efforts to achieve "intercultural media literacy" and acquire, in addition to digital competencies, the minimum basics of intercultural understanding which he could apply in practice in an unlimited internet environment.

Theoretical basis was followed by the own research, the aim of which was to identify and evaluate current topics that university students have the opportunity to see in discussions about different cultures on the Internet. The main method of own research was structured interviews. The results of the research provided students' perspective on the six most common topics that resonate in connection with different cultures on the current Internet. Respondents' answers consist of several experiences, own concerns or specific examples of topics about different cultures, students had faced on the Internet. Respondents' experiences have qualitatively character and have essential cognitive value.

In an effort to acquire the ability to acquire, in addition to digital competencies, the minimum basics of intercultural understanding (in the article we talked about the so-called "intercultural media literacy"), we believe is especially important education clear and effective explanation of key topics (e.g., state security policy, cyber security of the individual, etc.); online training on effective caution against misinformation and online fraud (e.g., hoaxes); multicultural initiatives in schools and other educational activities aimed at a multicultural society, including the strengthening of publishing activities in this area.

In our opinion, it is essential that not only schools but also regional and cultural institutions (libraries, museums and others) contribute to the effort to create opportunities through which the young generation can purposefully acquire intercultural media literacy. The cooperation of all components can, we believe, be an effective platform that contributes to a multicultural and virtual learning environment, both, in and out of the school environment. In addition, we consider the social dimension of the issue of cultural diversity to be an important aspect also of the public interest, including media interest.

The increase of intercultural media literacy can also be perceived as one of the goals of education, which contributes to the increase of the academic level, and to meet other academic goals; for example implement effective teaching strategies that reflect ethnic diversity, implementation of effective strategies in educa- 
tion that would contribute to reducing prejudice among students, reforming the curriculum to reflect the ethnic characteristics of students etc. Given the complexity, the number of areas covered by this topic, and the limitations of research findings, in the following section we will focus on proposals that could help in the effort to acquire intercultural media literacy, which was the subject of our interest in this article.

Among the specific initiatives and in the context of our findings, we recommend:

1. Actively support initiatives leading to the elimination of intolerant and radical attitudes in public debate and on the Internet; to promote bold, open, socially responsible journalism.

2. In school teaching, remove the black and white and West Centrist view of history (e.g. Christianity and Islam); incorporate intercultural and interfaith dialogue into the curriculum in order to educate the young generation that rejects radicalism (Nicolini, 2012).

3. Improve textbooks (e.g., also on translations of religious books of religions other than Christianity) and strengthen teacher training in relevant subjects; support initiatives to reduce prejudice in the school environment.

4. Create opportunities for young people to meet and collaborate in person; support young opinion leaders, budding journalists or bloggers in creating multicultural content.

5. Perceive the young generation as a priority of society, regional policies and state policy.

\section{References}

Boroš, J. (2001). Basics of social psychology. Bratislava: Iris. (In Slovak.)

Charvát, J. (2007). Contemporary political extremism and radicalism. Prague: Portál. (In Czech.)

Cortoni, I. (2017). Digital competence and family mediation in the perception of online risk to adolescents: Analysis of the Montenegro case study. International Journal of Media and Information Literacy, 2(2), 68-78. https://doi.org/10.13187/ijmil.2017.2.68

Cross, T.L., Bazron, B.J., Dennis, K.W., \& Isaacs, M.R. (1989). Towards a culturally competent system of care: A monograph on effective services for minority children who are severely emotionally disturbed. Washington, DC: CASSP Technical Assistance Center, Georgetown University Child Development Center.

Derman-Sparks, L., \& Phillips, C.B. (1997). Teaching/learning anti-racism: A developmental approach. New York: Teachers College Press, Columbia University.

Douglas, K. (2021). COVID-19 conspiracy theories. Group Processes \& Intergroup Relations, 24(2), 270-275. https://doi.org/10.1177/1368430220982068

Fedorov, A., \& Mikhaleva, G. (2020). Current trends in media and information literacy in research and scientific publications of the early 21st century. International Journal of Media and Information Literacy, 5(2), 153-163. https://doi.org/10.13187/ijmil.2020.2.153

Grác, J. (1985). Persuasion: Influencing man by man. Martin: Osveta. (In Slovak.)

Hall, S. (2013). Representation: Cultural representation and signifying practices. US: Sage Publications Ltd.

Hašková, A., Šafranko, C., Pavlíková, M., \& Petrikovičová, L. 2020. Application of online teaching tools and aids during corona pandemics. Ad Alta: Journal of Interdisciplinary Research, 10(2), 106-112. https://doi.org/10.33543/1002

Hobbs, R., \& Jensen, A. (2009). The past, present, and future of media literacy education. Journal of Media Literacy Education, 1, 1-11. 
Jirák, J., \& Kopplová, B. (2009). Mass media. Prague: Portál. (In Czech.)

Jones, W.H. (2003). Over the wall: Experiences with multicultural literacy. Journal of Marketing Education, 25(3), 231-240. https://doi.org/10.1177/0273475303257552

Khonamri, F., Azizi, M., \& Králik, R. (2020). Using interactive e-based flipped learning to enhance EFL literature students' critical reading. Science for Education Today, 10(1), 25-42. https://doi.org/10.15293/2685-6762.2001.02

Kondrla, P., Tkáčová, H., \& Tvrdoň, M. (2020). Social work and its impact on alleviating the social exclusion of religious minorities. ICERI 2020 Conference proceedings: 13th International Conference of Education, Research and Innovation (pp. 3844-3851). Seville: IATED.

Kozubík, M., Filakovská Bobaková, D., Rosinský, R., Mojtová, M., Tvrdoň, M., \& Dijk, J.P. van. (2020). Social structure in a Roma settlement: Comparison over time. International Journal of Environmental Research and Public Health, 17(19), 7311. http://dx.doi.org/10.3390/ijerph17197311

Lenč, J. (2017). Unwelcome foreigners: Muslims in Slovakia. In A. Bílá (Ed.), Muslims Are: Challenging Stereotypes, Changing Perceptions (pp. 167-180). Bratislava: Nadácia otvorenej spoločnosti. (In Slovak.)

McQuail, D. (2007). Introduction to the theory of mass communication. Prague: Portál. (In Czech.)

Mistrík, E. (2011). Objectives and content of multicultural education and training for the State Educational Program ISCED 0 and ISCED 1. Bratislava: State educational program. (In Slovak.) Retrieved from: https://www.statpedu.sk/files/articles/dokumenty/statnyvzdelavaci-program/mkv_isced_0_1.pdf

Murgaš, F., \& Petrovič, F. (2020). Quality of life and quality of environment in Czechia in the period of the COVID-19 pandemic. Geograficky Casopis, 72(3), 261-274. https://doi.org/10.31577/geogrcas.2020.72.3.13

Nicolini, B. (2012). The first sultan of Zanzibar: Scrambling for power and trade in the nineteenth-century Indian Ocean. Princeton, NJ: Wiener

Procházka, R., Šmahaj, J., Kolařík, M., \& Lečbych, M. (2014). Theory and practice of counseling psychology. Prague: Grada. (In Czech.)

Ramonet, I. (2003). Media tyranny. Prague: Mladá fronta. (In Czech.)

Reifová, I. (2004). Dictionary of media communication. Prague: Portál. (In Czech.)

Snow, C.C., Fjelstad, Ø.,D., \& Langer, A.M. (2017). Designing the digital organization. Journal of Organization Design, 6(7), 1-13. https://doi.org/10.1186/s41469-017-0017-y

Sue, D.W. (2001). Multidimensional facets of cultural competence. The Counseling Psychologist, 29(6), 790-821. https://doi.org/10.1177/0011000001296002

Šišková, T. (1998). Education for tolerance and against racism. Prague: Portál. (In Czech.)

Šmahel, D. (2003). Psychology and the Internet. Children by adults, adults by children. Prague: Triton. (In Czech.)

Veličková-Hulanová, L. (2012). Kybergrooming a kyberstalking. In B. Krčmářová, K. Vacková, J. Hýbnerová, L. Veličková-Hulanová, A. Langrová, B. Malíková \& P. Porubský (Eds), Children and Online Risks: Proceedings of Studies (pp. 87-110). Prague: Sdružení linka bezpečí. (In Czech.)

Vybíral, Z. (2002). Research of disinhibition in young chat users. In I. Plaňava \& M. Pilát (Eds). Children, Youth and Families in a Period of Transformation. Brno: Barrister \& Principal-studio. (In Czech.)

Webb, H., Jirotka, M., Stahl, B.C., Housley, W., Edwards, A., Matthew, W., Procter, R., Rana, O., \& Burnap, P. (2016). Digital wildfires: Hyper-connectivity, havoc and a global ethos to govern social media. ACM SIGCAS Computers and Society, 45(3), 193-201. https://doi.org/10.1145/2874239.2874267

Welnitzová, K., Jakubičková, B., \& Králik, R. (2021). Human-computer interaction in translation activity: Fluency of machine translation. RUDN Journal of Psychology and Pedagogics, 18(1), 217-234. https://doi.org/10.22363/2313-1683-2021-18-1-217-234 
Article history:

Received 11 August 2021

Revised 1 October 2021

Accepted 5 October 2021

\title{
For citation:
}

Tkáčová, H., \& Králik, R. (2021). Communication in a multicultural virtual environment for modern Slovak students. RUDN Journal of Psychology and Pedagogics, 18(4), 770-784. http://dx.doi.org/10.22363/2313-1683-2021-18-4-770-784

\section{Bio notes:}

Hedviga Tkáčová, Doctor of Philology, Doctor of Theology, is Assistant Professor at the Faculty of Arts and Letters, Catholic University in Ruzomberok (Slovakia). ORCID: 00000003-3062-2284. E-mail: hedwiga.tkacova@gmail.com

Roman Králik, Doctor of Theology, is Professor at the Medical Institute, Peoples' Friendship University of Russia (RUDN University) (Moscow, Russia); President of Kierkegaard Society in Slovakia and Central European Research Institute of Soren Kierkegaard (Sala, Slovakia). ORCID: 0000-0002-1929-1894. E-mail: roman.kralik73@gmail.com

\section{Современные словацкие студенты об общении в мультикультурной виртуальной среде}

\author{
Х. Ткачова ${ }^{1} \mathbb{D}$, Р. Кралик ${ }^{2} \unrhd$ \\ ${ }^{1}$ Католический университет в Ружомбероке, \\ Словачкая Республика, 034 01, Ружомберок, Грабовское шоссе, д. 1 \\ ${ }^{2}$ Российский университет дружбы народов, \\ Российская Федераџия, 117198, Москва, ул. Миклухо-Маклая, д. 6 \\ roman.kralik73@gmail.com
}

\begin{abstract}
Аннотация. В современном мире возрастает значимость развития у детей и молодежи умений межкультурного общения. Важную роль в этом процессе играет расширение, повышение открытости и доступности интернет-пространства, где встречаются разные люди с разными взглядами, интересами и желаниями. Сегодняшних молодых людей справедливо называют «цифровыми аборигенами», легко ориентирующимися в мультикультурной онлайн-среде, активно использующими современные технологии, которые уже стали неотъемлемой частью их повседневной жизни. Целями исследования стали анализ контекста мультикультурной онлайн-среды с точки зрения студентов словацких университетов, выявление и оценка наиболее актуальных тем возникающих в интернете дискуссий, которые связаны с культурными различиями. В качестве основного метода исследования выбрано структурированное интервью. Результаты интервью отразили мнения словацких студентов относительно шести наиболее распространенных тем, связанных с представлением различных культур в интернете: 1) беспокойство о собственной безопасности из-за «отличий от других»; 2) дезинформация в интернете относительно «отличия других»; 3) когнитивные предрассудки; 4) религиозные предрассудки; 5) преувеличение; 6) воздействие на эмоции аудитории. Утверждается, что современные молодые люди должны развивать не только способность ориентироваться
\end{abstract}


в виртуальной реальности, но и предпринимать ежедневные индивидуальные усилия по преодолению личных границ и развитию так называемой межкультурной медиаграмотности, которая понимается как способность приобретать, помимо цифровых компетенций, навыки межкультурного взаимопонимания и применять их на практике в процессе общения в интернет-среде.

Ключевые слова: поликультурная среда, виртуальная среда, межкультурная медиаграмотность, студенты, медиа, структурированное интервью

\section{История статьи:}

Поступила в редакцию: 11 августа 2021 г.

Принята к печати: 5 октября 2021 г.

\section{Для цитирования:}

Tkáčová H., Králik $R$. Communication in a multicultural virtual environment for modern Slovak students // Вестник Российского университета дружбы народов. Серия: Психология и педагогика. 2021. Т. 18. № 4. С. 770-784. http://dx.doi.org/10.22363/2313-16832021-18-4-770-784

\section{Сведения об авторах:}

Ткачова Хедвига, доктор филологических наук, доктор богословия, доцент факультета искусств и литературы, Католический университет в Ружомбероке (Словакия). ORCID: 0000-0003-3062-2284. E-mail: hedwiga.tkacova@gmail.com

Кралик Роман, профессор, доктор богословия, Медицинский институт, Российский университет дружбы народов (Москва, Россия); президент Общества Кьеркегора в Словакии и Центральноевропейского исследовательского института Серена Кьеркегора (Сала, Словакия). ORCID: 0000-0002-1929-1894. E-mail: roman.kralik73@gmail.com 